\title{
PROFESINIO IDENTITETO FORMAVIMASIS SOCIALINIO DARBO PRAKTIKOJE: KOMUNIKACINĖS KOMPETENCIJOS AKTUALIZAVIMAS
}

\author{
Julija Eidukevičiūtė, Nijolè Petronèlė Večkienė \\ Vytauto Didžiojo universitetas
}

\begin{abstract}
Anotacija
Straipsnyje siekiama pagrįsti komunikacinès kompetencijos aktualumą socialinio darbo profesinio tapsmo procese. Atsižvelgiama ị sąvokos socialinis sąsajas su ekonomikos, politikos kryptimis bei prioritetais, socialinio darbo pokyčiais praktikoje, pabrežiant komunikaciją kaip veiklos ir patirtinio mokymosi galimybę bei šaltinị. Remiantis teorinès ir empirinès analizès rezultatais, analizuojamas pagalbos šeimai procesas, akcentuojant galimybę plètoti komunikacinę kompetenciją individualios intervencijos procese ar grupeje. Straipsnyje laikomasi mokymosi paradigmos ir socialinio igalinimo metodologinių nuostatų, išryškinančių aktyvaus ir atsakingo veikëjo poziciją, bendradarbiavimo reikšmę, lemiančias profesinès veiklos sėkmę. Straipsnio pradžioje aptariamas dinamiškas ir nuolat kintantis socialinio darbo kontekstas, lemiantis tarpasmeninès komunikacijos trukdžius ir problemas, pagrindžiama komunikacinès kompetencijos plètotès būtinybè. Analizuojant mokymosi konstruoti igalinantị santykị su šeima teorines galimybes, aptariamas patirtinio mokymosi procesas, apibūdinama jo struktūra, dalyvių tarpusavio komunikacija, lemianti turinio konstravimą, naujų žinių kūrimą. Išryškinamos empirinès profesinio identiteto formavimosi prielaidos, atskleidusios ,pasilikimą“ pirminèje profesionalizacijos proceso fazèje. Aktualizuojant komunikacinès kompetencijos plètotę pagalbos šeimai procese, atskleidžiami esminiai profesionalizacijos nuostatų realizavimo trukdžiai, nulemti socialinių darbuotojų ir šeimos, kaip kliento, komunikacijos problemų. Atskleidžiama praktiko eksperto arba supervizoriaus palydejjimo būtinybė patirtinio mokymosi procese, formuluojama j̇žvalga, kad toks palydèjimas iggalina praktiką pasitelkus refleksiją plètoti savo, kaip socialinio darbuotojo, profesionalumą.

PAGRINDINIAI ŽODŽIAI: profesionalizacija, pagalbos procesas, šeima, komunikacinė kompetencija, patirtinis mokymasis, refleksija.
\end{abstract}

\begin{abstract}
The article aims to justify the relevance of communication competence in the process of professional development. There is taken into consideration the connection of concept "social" with trends and priorities of economy and policy, changes in social work practice, emphasizing the communication as possibility and source for professional action and experiential learning. On the basis of theoretical and empirical results of analysis there is discussed the helping process for the risk family and the possibility to develop the communication competence in the process of individual intervention or group intervention. At the first part of article the learning paradigm and social empowerment methodological guidelines, which emphasize the position of active and responsible character and the meaning of collaboration, which determine the success of professional activity. There is discussed the context of the social work, which impact interpersonal communication obstacles and arising problems, the necessity to develop communicative competence is emphasized. Analyzing theoretical assumptions for learning in practice construction with aim to develop empowering relationship with family, there is discussed experiential learning process, definition of its structure, reciprocal communication, construction of practice content, the creation of new knowledge. The results of qualitative research revealed the problems of communication between social worker and family as a client. Social worker
\end{abstract}


with sufficient practical activity experience usually remains in the primary phase of help process contact establishment. In one case family proactiveness is expected but it remains "invisible". The research revealed the individual process of experiential process the necessity of practitioner-expert or supervisor coaching in the experiential learning process by self-assessing and combining practical knowledge which were gained by acting in practice placement, theoretical knowledge and created professional knowledge. Such coaching enables to systematize elements recurring in situations, develop their professionalism of social worker with the help of reflection.

KEY WORDS: professionalization, helping process, risk family, communicative competence, experiantal learning, reflextion.

DOI: http://dx.doi.org/10.15181/tbb.v68i4.948

\section{Ivadas}

Vienas esminių žinių visuomenès bruožų ir pagrindinis jos iššūkis - multidisciplininis šios visuomenès pobūdis, aktualizuojantis mokymąsi susikalbèti užsiimant veikla, kurioje dalyvauja skirtingi individai, ịvairių subkultūrų atstovai (Brunevičiūtè ir kt., 2011). Tokioje visuomenejje žmogui kyla vis nauji reikalavimai, lemiantys asmens ir aplinkos sąveikos kaitą, kintančius poreikius, ilgalaikes naujas problemas (Večkienė, 2011). Kita vertus, žmogiškujų išteklių ir kiekvieno žmogaus savarankiško gyvenimo galimybių išsaugojimas ir plètote tampa esminiu žinių visuomenès bruožu. Šioje kultūrinèje-socialinëje terpẻje, kaip būtina, iškyla susikalbèjimo sąlyga. Tačiau objektyvi žinių visuomenès realybė - mokslų konvergencija, galinti sukelti paskirų veiklos sričių atstovų susikalbėjimo sunkumų. Nepripažįstant šios realybès, vargiai tikètinas skirtingų socialinès veiklos sričių, skirtingų profesijų atstovų, dirbančių vienoje organizacijoje, vienoje projekto komandoje susikalbejjimas (Brunevičiūte ir kt., 2011). Ieškant galimybių susikalbèti, būtina sudaryti sąlygas plètoti bendradarbiavimo patirtị. Tačiau pastarojo dešimtmečio mūsų tyrimai minètoje srityje išryškino nepakankamą socialinio darbo profesionalų komunikacinę kompetenciją, keliančią esminį bendradarbiavimo klausimą, ar galima ir kaip galima mokytis susikalbėti? (Brunevičiūtė ir kt., 2011; Eidukevičiūtè ir kt., 2005).

Socialinis darbas - tai empirinès prigimties veikla, ieškant savojo identiteto, tai kintanti profesija, nes socialinio darbo paskirtis yra socialinių problemų, kylančių sąveikaujant asmeniui, bendruomenei ir visuomenei, sprendimas. Socialinis darbuotojas, siekdamas optimizuoti kliento gyvenimo situaciją ir jo aplinką, kuri visada yra kompleksinè, ieško sprendimo galimybių, taiko ịvairių mokslų žinias. Teikdamas pagalbą šeimai socialinis darbuotojas susiduria su šeimos, kaip vieneto, kompleksiškumu, kiekvieno šeimos nario individualumu, unikalia patirtimi.

Straipsnio tikslas - remiantis teorinès ir empirinès analizès rezultatais aptarti pagalbos šeimai procesą ir galimybę plètoti komunikacinę kompetenciją indivi- 
dualios intervencijos procese ar grupeje, atliepiant žinių visuomenès iššūkius bei nuolatinius pokyčius. Straipsnio problematiką galima apibūdinti remiantis P. Bourdieu (1994) teiginiu, kad žinių objektai yra konstruojami, ne užrašomi. Socialinis darbuotojas sąveikaudamas su klientu kuria savo profesinị elgesị, kalbą, laikyseną, taip plètodamas savaji veiklos pasaulio pažinimą. N. Večkienè (2010) pastebi, kad socialinių darbuotojų kompetencija praktikoje reiškiasi savitai: konkrečiai sąveikaudami su klientu jie savitai realizuoja vertybines nuostatas, igytas žinias, igūdžius. Siekiant giliau suprasti profesinio identiteto formavimosi procesą būtina atsižvelgti ị P. Bourdieu teorinị teiginį, kad egzistuoja dialektinè sąveika tarp lauko (objektyvių struktūrų) ir habitus (mentalinių, kognityvinių struktūrų, kurių dèka žmogus veikia socialinèje erdvėje). Viena vertus, laukas lemia habitus, kita vertus, būtent habitus suteikia laukui prasmę ir padaro jị vertingu. Habitus, pasak P. Bourdieu (1994), yra istorinis produktas, kuris lemia individualias ir kolektyvines praktikas, atitinkančias istoriškai generuotas schemas. Habitus formavimuisi didžiulę reikšmę turi tai, kaip ir kur mes augome, gyvenome, kaip vyko mūsų socializacija, kokia tvarka vyravo namuose. Svarbu tai, kad habitus užtikrina praktikos „taisyklingumą“ ir jos pastovumą, praeities patirčių aktualumą dabarčiai. Konkreti praktika yra patikimesnè, nei visos formalios taisyklès ar aiškiai išsakytos normos. Tačiau mentalinès struktūros, P. Bourdieu (1994) teigimu, nebūtinai kinta paraleliai ir taip pat sparčiai kaip socialinès. Kuo sąlygos labiau pakitusios ir skiriasi nuo pradinių, tuo sunkiau individui apsispręsti ir veikti. Šiame kontekste išryškejja tam tikras paradoksas. Pagalba šeimai teikta ir tarybiniais laikais. Tačiau tuo metu tèvai ir vaikai turèjo laikytis valstybės nustatytų krypčių, atitikti valstybės nustatytas normas ir, svarbiausia, ideologiją. Individualūs sprendimai, asmeninės vertybès nebuvo pageidaujami, netgi negalimi. Šiuolaikinis požiūris ị šeimą ir jos atsakomybę yra iš esmès kitoks. Šeima suprantama kaip pirminè ir svarbiausia vaiko socialinė sistema, prisiimanti pagrindinę atsakomybę už jo / jos socialinę raidą. Todèl socialinių darbuotojų ir šeimos santykis pagalbos procese taip pat turètų iš esmès skirtis. Tačiau pavojingu trukdžiu, kuriant igalinančios pagalbos santyki, formuojantis šiuolaikinị kontekstą atitinkančiam socialinio darbuotojo, socialinio pedagogo profesiniam identitetui, gali tapti nepakankamai reflektuojama istorinè patirtis, menkas kultūrinio konteksto pažinimas.

Straipsnyje laikomasi mokymosi paradigmos ir socialinio igalinimo metodologinių nuostatų, išryškinančių aktyvaus ir atsakingo veikejjo poziciją bei bendradarbiavimo reikšmę, lemiančias profesinès veiklos sėkmę. Straipsnị sudaro: ịvadas, 3 dalys ir išvados. Pirmoje dalyje aptariamas socialinio darbo kontekstas, lemiantis tarpasmeninès komunikacijos trukdžius ir kylančias problemas, išryškinama komunikacinès kompetencijos plètotès būtinybè. Antroje dalyje aptariamos teorinės mokymosi kurti ịgalinantị santykị su šeima galimybès, pabrèžiant patirtinio moky- 
mosi procesą praktikoje ir jo dalyvių tarpusavio komunikaciją. Trečioje straipsnio dalyje, remiantis disertacinio tyrimo rezultatais (Eidukevičiūtè, 2013), analizuojamos empirinès profesinio identiteto formavimosi prielaidos, aktualizuojant komunikacinès kompetencijos plètotę pagalbos šeimai procese.

\section{Komunikacinės kompetencijos aktualizavimas pokyčių kontekste}

Globalizacijos procesai lemia intensyvius pokyčius ịvairiose mūsų gyvenimo srityse. Pokyčius lydi nuolat kintantys ir didejjantys žmogui keliami reikalavimai (Bell, 2003), kurių dinamika lemia nuolatinę žinių plètrą ir kaitą, sukuria nuolatinio mokymosi prielaidas. Pokyčiai dažnai siejami su tokiais XXI amžiaus visuomenių apibūdinimais: poindustrinè, postmodernistinè, paslaugų, vartojamoji, žinių visuomenè. Analizuojant literatūrą išryškèja esminè globalizacijos ypatybė: šiam reiškiniui apibūdinti būtinos trys dimensijos - politinè, socialinè, ekonominè. Laikantis tokio požiūrio straipsnyje pagrindžiamas komunikacinès kompetencijos plètotès aktualumas profesinio identiteto formavimosi procese. Akivaizdu, kad pagalbos žmogui samprata sukuria prielaidas skirtingų mokslo ir praktikos sričiu specialistų bendradarbiavimui, kas atitinka socialinio darbo kompleksiškumą pagalbos šeimai procese.

P. Bourdieu (1994) teigimu, dialektinè sąveika tarp lauko ir habitus generuoja mūsų veiksmus, strategijas ir tai, kaip mes suvokiame pasauli. Taigi habitus kartu yra ir praktikų kūrimo, ir jų supratimo bei vertinimo sistema. Abiem atvejais išryškejja socialinès situacijos, kurioje habitus formavosi, lemiama reikšmė. P. Bourdieu teigia, kad kuo labiau socialinès struktūros atitinka tas, kuriose formavosi habitus, tuo mažiau reikia specialiai svarstyti žmogaus kasdienę veiklą, nes ji yra nesąmoninga. Autorius tai vadina praktikos logika. Lietuvos atveju sąlygos iš esmès pasikeitusios, palyginus su pradinèmis, todèl socialiniam darbuotojui gali būti sunkiau apsispręsti ir veikti.

Yra dar vienas, glaudžiai su nagrinėjama tema susijęs P. Bourdieu teorijos aspektas, teigiantis, kad ị lauka galima žiūrèti kaip ị struktūruotą pozicijų erdvę, kur pozicijos ir jų tarpusavio ryšiai nulemti skirtingos rūšies kapitalo paplitimo (Bourdieu, 1994). Individo pozicijos lauke priklauso nuo jo valdomo kapitalo dydžio ir skirtingų disponuojamų kapitalų (ekonominio, kultūrinio, socialinio, simbolinio) santykio. Čia taip pat galima atrasti ryškių pokyčių ir manyti, kad jie nevienodai veikè skirtingą socialinių grupių, mūsų atveju šeimos, gyvenimą. Keltina hipotezé, kad tarybinių laikų socialinè struktūra pripratino žmones laukti, kol kas nors jais pasirūpins, aktyvumas ir iniciatyva paprastai buvo nereikalingi ir net slopinami. 
Tačiau pasikeitusi situacija, ypač ekonomikos srityje, šiuo metu skatina aktyvumą darbo rinkoje, verslumą, t. y. kitokią praktiką.

Svarstant socialinio darbo profesinio identiteto klausimą labai svarbu įvertinti simbolinio kapitalo kaitą. Simbolinès vertybès, kuriomis grịstas žmonių reikšmingumas ir prestižas, pokyčių laikotarpiu kinta. P. Bourdieu teorijas perkèlus ị Lietuvos socialinio gyvenimo praktiką, galima kalbèti apie dar vieną bendradarbiavimo kliūčių ir tyrimų sritị: pokyčiai buvo tokie greiti ir radikalūs, kad senasis habitus liko beveik nepakitęs, vis dar egzistuoja naujoje socialinejje erdvèje ir neleidžia išnaudoti objektyvių galimybių, esančių šioje socialineje erdvejje. Habitus yra linkęs išsaugoti savo pastovumą ir ,gintis“ nuo pokyčių, atmetant tai, kas gali paneigti informaciją, suformavusią mūsų habitus.

Minèti psichosocialinio konteksto ypatumai leidžia teigti apie išsamios pokyčių analizės aktualumą Lietuvos socialinèje erdvejje, išryškinant pagalbos šeimai trukdžius bei galimybes. Tai patvirtina Vytauto Didžiojo universiteto Socialinio darbo katedros darbuotojų tyrimai ir studentų diplominiai darbai, kuriuose analizuojamas socialinio darbuotojo vaidmuo skirtingose pagalbos žmogui srityse. Šie darbai atskleidžia paradigminę kaitą išgyvenančio ir tik trečią dešimtmetị Lietuvoje pradejjusio socialinio darbo įvaizdžio bei statuso problemiškumą.

Dažnai komunikacija apibrēžiama kaip paskirų individų, kurie save identifikuoja kaip skirtingus nuo kitų patirties pagrindu, tarpasmeninè sąveika. Žmonių vertybių sistemos, tikejjimas ir tam tikros normos, kurios konstruoja tam tikrą jiems būdingą realybę, skiriasi. Kiekvienas žmogus turi tam tikrus jausmų, mąstymo, galimo veikimo ar neveikimo kriterijus, scenarijus, kurių išmokstama per visą gyvenimą. Akivaizdu, kad nuo skirtumų suvokimo ir gebejjimo susikalbèti priklauso socialinès pagalbos organizavimas ir teikimas rizikos situacijoje esančiai šeimai.

Todèl komunikacijos sritis ypač svarbi analizuojant tarpasmeninę žmonių sąveiką individualios intervencijos procese ar dirbant su vaiku ir jo šeima. Norint būti kompetentingu šioje srityje, reikia atkreipti dèmesị ị asmenybès pažinimą, komunikacinius ịgūdžius, psichosocialinį palaikymą, kultūros pažinimą. Nagrinėjant šią sritị detaliau, svarbu paminèti adaptavimosi prie naujos situacijos momentą, kuris gali sukelti kultūrinị šoką, lydimą baimès, streso, nepritarimo, svetimumo jausmų. Tai apima žmogaus nustebimą, juoką ar pasimetimą, kai girdi svetimą kalbą (Grebliauskienè, Večkienè, 2004). Kita vertus, tai yra socialinių profesijų atstovų kasdienybė, nes klientų ar besimokančiųų psichosocialinė situacija kinta kiekvieną dieną. Profesionalui kasdien tenka spręsti santykio užmezgimo, palaikymo ir plètojimo problemas. 
Filologijos požiūriu, susikalbèti reiškia susižinoti, susišnekèti tarpusavyje, tai yra perduoti, pranešti žinią. Susikalbèti reiškia suprasti - suvokti prasmę, esmę, išmanyti, suvokti, sutikti, sutarti. Filologija leidžia pažinti susikalbẻjimą kaip objektą, atskleidžiantị svarbų santykị tarp kalbos, mokymosi, žinojimo, naujų žinių kūrimo (Brunevičiūtè ir kt., 2011).

Komunikacijos mokslo požiūriu, susikalbèjimas - tai reikšmių kūrimas ir keitimasis jomis, kai žinia yra tam tikras objektas, ženklų konstrukcija (Brunevičiūtė ir kt., 2011). Tik abipusès abiejų šio proceso veikejjų pastangos lemia, kokia bendra reikšmė bus sukurta. Komunikacijos sẻkmė priklauso nuo to, kaip siunčiamo pranešimo reikšmė atitinka gavẻjo socialinę patirtị ar kultūrą, kiek tikslingas yra pranešimo perdavimo / prièmimo procesas. Edukologijos požiūriu, susikalbèjimas - tai suderinta mokymo ir mokymosi veikla, kai veikiama toje pačioje paradigmoje, pagal tą patị ugdymo modelį. Tradiciškai mokymo tikslas - informacijos perdavimas, o mokymosi tikslas - informacijos peremimas. Mokymosi paradigmos kontekste, mokymosi, kaip informacijos prièmimo ir atkūrimo, samprata tampa interaktyvaus dinamiško ieškojimo proceso, kuriame tyrinejant bei sąveikaujant su aplinka gimsta naujas supratimas, samprata (Brunevičiūtė ir kt., 2011). Mokymosi procese žmonès plètoja savo žinias, supratimą, gebėjimus, vertybes, požiūrius, patirtị.

Minètos filologinès, komunikacinès ir edukacinès mokymosi susikalbèti prielaidos leidžia aktualizuoti komunikacinès kompetencijos plètotès profesinio identiteto formavimosi procese klausimą, kuris plačiau aptariamas antroje straipsnio dalyje.

\section{Patirtinio mokymosi ypatumai igalinančio socialinio darbo praktikoje}

Šioje dalyje pristatomi patirtinio mokymosi ir profesionalizacijos raidos modeliai, akcentuojamas socialinio darbuotojo, kaip konsultanto, vaidmens reikšmingumas, detalizuojami kiekvieno profesionalizacijos etapo ypatumai, lemiantys tarpusavio komunikacijos ir pagalbos kokybę (Bernar, 2002; Dreyfus, Dreyfus, 1980). Literatūroje ir dokumentų tekstuose, kurie skirti socialinès veiklos teorijai ir praktikai, pabrèžiami žmogiškieji ištekliai, kurie lemia gamybinius, ekonominius rodiklius. Kita vertus, socialinis kapitalas gali padèti realizuoti žmogiškojo kapitalo potencialą. Bendruomenės, kurių aukštas socialinio kapitalo lygis, pasiekia geresnių rezultatų, palyginus su bendruomenemis, kurios susiduria su socialine fragmentacija ir izoliacija. Vyriausybès negali tiesiogiai padidinti socialinio kapitalo, bet gali sukurti palankią aplinką investuoti ị jị. Pavyzdžiui, švietime ir tobulinimosi kursuose daugiau dèmesio galima skirti komunikacijos ịgūdžiams lavinti, 
nes jie yra labai svarbūs, skatinant tarpusavio pasitikèjimą ir ekonominį aktyvumą (Večkienè, 2010).

Komunikacinès kompetencijos svarbą patvirtina ir kintantis darbo pobūdis. Dèl ìvairių politinių, ekonominių, visuomeninių pokyčių Lietuvoje stebimas gyventojų populiacijos judejjimas iš pramonès ị paslaugų sriti, atsiranda naujas kliento ir gamintojo / paslaugos teikejjo santykis, keičiasi visuomenès vertybès. Tai patvirtina D. Bell (2003), analizavęs industrinị ir poindustrinị darbą, gyvenimo bei veiklos šiose skirtingose visuomenèse ypatumus. Jis pabrèžia, kad prekes gaminančiose racionaliose visuomenèse asmuo ir jo vaidmuo atsiskiria, didejja individualizacija, susvetimejjimas. Kita vertus, dèmesys sutelkiamas ties humanitarinėmis, profesinėmis ar technologinėmis paslaugomis, santykiai tarp individų lemia veiklą. Šių prieštarų kontekste planuojant socialinių profesijų pokyčius svarbu nepamiršti, kad poindustrinès visuomenès ,socialinis vienetas yra ne individas, o bendruomenès organizacija“" (Bell, 2003, p. 223). Taip pabrèžiamas bendradarbiavimo ir savitarpiškumo prioritetas koordinavimo ir hierarchijos atžvilgiu. Taigi komunikacinių gebejimų svarba tampa dar akivaizdesnè.

Profesionalų ir klientų bendradarbiavimas pagalbos žmogui procese skatina toleranciją ir dialogą, kuris įmanomas, jei laikomasi ịgalinimo nuostatos. Todèl išgyvenant socialinių profesijų kaitą esminè yra dvejopos mainų patirties refleksija: patirties, sukauptos bendradarbiaujant tarp skirtingų šalių, ir tarp skirtingų socialinių profesijų (Lorenz, 1998). Šiuolaikinę igalinimo kompetenciją socialiniame darbe apibrěžiančių tekstų analizè leidžia teigti, kad kiekviena situacija, kurioje atsiduria profesionalas, gali būti specifiška. Be to, socialinès pagalbos proceso ypatumas yra tas, kad ne tik profesionalas susiduria su nuolat besikeičiančiomis sąlygomis, pastarosios verčia keistis ir paslaugų gavejją. Taip išryškejja dvi tendencijos, kurios lemia socialinių profesijų ir pasirengimo joms pokyčius. Pirma, socialinè veikla orientuojasi į kliento aktyvumą, nes jis pats aktyviai dalyvauja problemos sprendimo procese. Antra, profesionalas dažnai veikia kaip igalintojas (Pyne, 1996). Jis didina kliento motyvaciją, užtikrina tokị pagalbos procesą, kuris padidina asmeninę, tarpasmeninę, siocioekonominę ir politinę galią, padeda gerinti aplinkos sąlygas, pasiekti numatytą pokytị (Comton, Galaway, 1999). Šiame kontekste svarbu pabrěžti esminę socialinès veiklos nuostatą - paslaugos gavėjo situacija keičiasi tik kliento pastangų dẻka.

Kadangi socialinio darbuotojo veikla daugiausiai sutelkta ties asmens ir aplinkos sąveikos optimizavimu, kuris dèl kliento ir jo situacijos individualumo visada komplikuotas bei kompleksiškas, darbuotojas turètų veikti kaip komunikacijos organizatorius, padėdamas asmeniui atkurti ar sukurti ryšius, kurie leistų pasinaudoti aplinkoje esančiais ištekliais ar galimybėmis (Kavaliauskienè, 2005; Campton, 
Galaway, 1999). Minètame kliento ir aplinkos sąveikos optimizavimo procese dažniausiai dalyvauja keli specialistai, turintys skirtingą profesinès veiklos patirtị ir skirtingą komunikacinę kompetenciją.

Praktikai ekspertai turètų padèti pradedantiems, dar besimokantiems socialiniams darbuotojams igyti praktinès patirties kartu veikdami konkrečioje organizacijoje. Žinojimas gali būti plètojamas, iggytą patirtị reflektuojant bendrosios patirties ir teorinių bei praktinių žinių kontekste, keičiant turètus ịsitikinimus, randant sąsajų tarp teorinių žinių ir praktikos (Večkienè, Eidukevičiūtė, 2009). Norèdami igyvendinti savo siekius ir veikti profesionaliai, socialiniai darbuotojai savo veikloje turètu gebėti taikyti refleksyvujị apmąstomaji socialinio darbo kompetencijos plètotès modelį, kuris pabrèžia teorijos ir praktikos ryšio būtinumą, asmeninès ir profesinès patirties sąveiką, pastaroji labai svarbi socialinio darbuotojo profesinio tobulëjimo procese (Dirgelienè, 2008).

P. Burnard (2002) patirtinio mokymosi sampratos modelis (žr. 1 pav.) leidžia aiškiau suprasti mokymosi praktikos turinį, dalyvių vaidmenis ir bendradarbiavimo svarbą. Pirmasis modelio elementas - asmeninè patirtis - reikšmingas dèl aktyvaus asmens ịsitraukimo ị mokymosi situaciją. Atliekant šią veiklą svarbus didesnę patirtį turinčio profesionalo palydejjimas. Praktinė veikla turètų įtraukti visas besimokančiojo pažinimo galimybes: mąstymą, jausmus, elgesị ir net kūno pojūčius. Antrasis elementas - refleksija - svarbus, siekiant realizuoti mokymosi procesą. Kai kas nors įvyksta, turime galimybę apsvarstyti buvusius ịvykius, tačiau kartais juos pastebime, bet nesvarstome, todèl neịsimename. Refleksijos procesas, dalyvaujant konsultantui, padeda pažinti save kaip būsimą profesionalą, skatina susieti teorines ir praktines žinias. Trečiasis elementas - žinių ir prasmių transformacija, kuri nevyks, jei nebus refleksijos. Šiuo požiūriu reikšmingos grupès supervizijos, kur vedančiojo užduotis - sudaryti galimybes, kad grupès nariai, reflektuodami patirtį, galètų mokytis ir igyti žinių apie profesinį veikimą, kuris leistų plètoti profesinį identitetą. Kritiškas mąstymas, klausimų kèlimas, t. y. intrapersonalinè ir tarpasmeninè komunikacija, yra svarbūs gebejjimai, reflektuojant grupejje, nes praplečia pažinimo lauką ir yra susiję su apsvarstymu, patikrinimu, analizavimu, vertinimu.

Taigi mokomasi atliekant veiksmą. Jei mokymosi procese, kalbant apie tarpasmeninius santykius, elgesys nesikeičia, jei neplètojama komunikacinè kompetencija, mokymasis nevertingas. P. Burnard (2002) teigimu, praktinis mokymasis kyla iš teorinių ir praktinių žinių integravimo. Pagrindiniai šio proceso bruožai: akcentuojamas veiksmas, žmogaus patirtis vertinama kaip mokymosi šaltinis, pabrèžiama asmens patirtis, besimokantieji skatinami reflektuoti savo patirtị, aiškinamasis vaidmuo suteikiamas grupès vedančiajam / supervizoriui. 


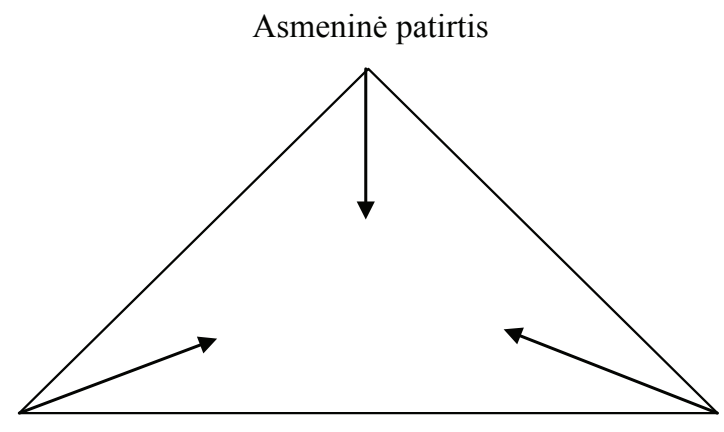

Žinių ir prasmių transformacija

Refleksija

1 pav. Patirtinio mokymosi sampratos modelis (Burnard, 2002)

Fig. 1. Model for understanding of the experiantal learning (Burnard, 2002)

Gebèti iš paskirų, tarpusavyje nesusijusių kliento tikrovès fragmentų suformuoti darbinę problemą, pajausti profesijos galimybes ir ribas, veikti dažnai chaotiškoje ir fragmentiškoje situacijoje pradedančiajam (ir ne tik) socialiniam darbuotojui gali būti pernelyg sudètinga. Nors visada yra galimybė praktinèje situacijoje išbandyti, kas veikia ir kas ne, nereikia pamiršti, kad šių bandymų objektas yra asmuo - organizacijos paslaugų gavejjas. Taigi eksperimentas atrodo neetiškas ir pavojingas. Todèl patirtinio mokymosi procese labai svarbi yra besimokančiojo bei ji / ją lydinčių profesionalų - praktiko eksperto, dèstytojo, supervizoriaus - tarpasmeninė komunikacija. Taip sąveikaujant kuriamas mokymosi proceso turinys (Eidukevičiūtè, 2011).

Mokymosi procesas nèra statiškas, galimas kasdienejje profesinèje veikloje, tačiau patyrimas ir įgūdžiai iggyjami ne iš karto. S. E. Dreyfus, H. L. Dreyfus (1980), pirmieji pasiūlę penkių pakopų mintijimo raidos modelį, akcentuoja skirtingą keturių mintijimo operacijų (ịsiminimo, atpažinimo, sprendimo, suvokimo) raišką atitinkamuose profesionalumo plètotès proceso etapuose. Kiekviename nuosekliai realizuojamame etape (naujokas - kompetentingas - igudęs - ekspertas - meistras) kinta profesionalo veikimas, jo gebejjimai ịvertinti situaciją ir priimti sprendimus. Patirtinio mokymosi požiūriu reikšmingas S. Žorga (2006) keturių profesionalumo raidos etapų modelis, akcentuojantis socialinio darbuotojo konsultanto vaidmenị ir tam būtiną komunikacinę kompetenciją. S. Žorga (2006) teigia, kad pačioje veiklos pradžioje besimokančiajam būdingas pasyvaus stebinčiojo ir priimančiojo vaidmens keitimas ị aktyvų socialinio darbuotojo vaidmenį. Šis perejjimas besimokančiajam sukelia vaidmens ir veiklos netikrumą, dvejones, jaučiamas nesaugumas, kritiškumas savo atliekamam vaidmeniui, išgyvenami netikrumo, bejègišku- 
mo, nekompetencijos jausmai, dažniausiai susitelkiama ties konsultavimo technikomis, bandoma tiesiogiai taikyti turimas teorines žinias.

Pirmajame (naujokas) etape labai svarbios instrukcijos (Dreyfus, Dreyfus 1980), kurios padeda suvokti organizacijos taisykles, ribojančias atliekamus veiksmus. Taisyklès ir praktiko eksperto palydèjimas, skatinantis nuolat ịsivertinti, leidžia pradedančiam socialiniam darbuotojui mokytis ir tobulinti savo veiklą praktiškai. Šiame etape išgyvenami du paraleliai vykstantys procesai: formuojasi profesijos identitetas ir mokomasi užmegzti dalykine komunikacija grindžiamą santykị su klientu, siekiant surasti problemų sprendimo būdą (Campton, Galaway, 1999). Antrajame (kompetentingas) raidos etape pradedantieji vis labiau atpažista savo galimybes, trūkumus ir galimą santykio poveikị klientui (Žorga, 2006). Vis dar jaučiama įtampa ir netikrumas, tačiau jau bandoma rizikuoti, pasirinkti komunikacijos modeli, leidžiantị atskleisti save klientui, dideja tolerancija neapibrèžtoms konsultavimo situacijoms. Šiame etape gebama susitelkti ties klientu, jo / jos gebejjimais ir poreikiais, konstruoti dialogu grindžiamą tarpasmeninès komunikacijos procesą, prisiimti atsakomybę už jo vyksmą ir rezultatus, suvokiant konsultavimo svarbą.

Kompetencija atsiranda, igijus pakankamai patirties, kuri padeda ịveikti konkrečias praktines situacijas (Dreyfus, Dreyfus, 1980). Pradedantieji jau pastebi tam tikrus besikartojančius situacinius komponentus ir geba sieti juos su organizacijos kontekstu. Kol kas jie dar neturi tiek patirties, kad gebètų ją apibendrinti iki abstrakčių sampratų, todèl būtina, kad lydètų praktikas ekspertas, padedantis atpažinti ir pasiruošti prasmingus veiklos elementus, pagrịstus asmenine ir profesine patirtimi, daugiau dėmesio skiriant konsultavimo ịūdžių lavinimui, grịžtamojo ryšio užtikrinimui komunikacijos procese. Vienas iš nuolatinį mokymąsi skatinančių būdų šiame etape yra ịgalinimas, t. y. pasitikèjimo savimi didinimas ir žinių, leidžiančių keisti savo profesinius veiksmus, plètote. Siekiant savarankiškumo ir autonomiškumo, būtina atsakomybė už savo veiksmų padarinius arba savimonė, galimybių paieška profesinès patirties plètotès procese turètų išlikti kaip besimokančiojo interesas (Grossman, 2007).

H. L. Dreyfus (1997) skiria kompetentingo darbuotojo, besimokančio iš savo patirties, mintijimo ir veikimo bruožus. Igijęs daugiau patirties darbuotojas žino daugiau praktinių situacijų, kurias geba susieti ir atpažinti tam tikrus besikartojančius elementus, tačiau sisteminti, formuluoti abstrakčiu įžvalgų dar nepajègia. Naujoko palydejimas patirtinio mokymosi procese gali būti tokiam darbuotojui dar viena atsakomybès reikalaujanti veikla. Vienas didžiausių iššūkių šioje situacijoje yra dialogo komunikacijos procese užtikrinimas, kur svarbu pasitikèti savo profesionalumu ir pradedančiojo gebejjimais savarankiškai atlikti konkrečią veiklą. 
S. Žorga (2006) teigia, kad trečiame profesionalumo raidos etape (igudęs) gerokai raiškesnè ilgalaikè motyvacija socialiniam darbui. Šiame etape socialinis darbuotojas geba susiderinti su kliento poreikiais ir organizacijos reikalavimais, siekdamas atitinkamo konsultavimo proceso rezultato. Profesionalas geba atrasti pusiausvyrą tarp mąstymo ir veikimo savo profesinejje veikloje, žino stipriąsias ir silpnąsias vietas, turi pageidaujamų klientų grupę. Darbuotojas turi daugiau profesinių teorinių žinių ir praktikos, labiau pasitiki savo profesine ir komunikacine kompetencija.

Socialiniai darbuotojai, turintys pakankamai patirties atlikti ekspertizę, susidūrę su praktinėmis situacijomis, nebesiekia atkurti daugialypès veiksmų sekos, priimdami sprendimus nebeatlieka kiekvieno veiksmo detalaus įvertinimo, bet pasitelkia intuiciją. Sprendimų prièmimas apima visą individualaus atvejo kontekstą, tačiau ekspertas patikrina ir gilinasi ị problemiškas, sudètingas situacijas, kai nepakanka tik intuityviai veikti. Tenka atsižvelgti ị neịprastas, rizikingas, atsakomybès reikalaujančias situacijas arba savo veiksmus ir sprendimus pagrịsti vadovui ar klientui. Socialinis darbuotojas ekspertas (ketvirtasis raidos etapas), pasak H. L. Dreyfus (1997), turi pakankamai patirties duoti patarimų, diagnozuoti ir vertinti, siūlyti sprendimus ir rekomendacijas realioms situacijoms. Profesinès veiklos meistriškumas (penktasis raidos etapas) leidžia plèsti socialinio darbuotojo eksperto kompetencijas, palydint mažiau patirties turintį kolegą. Šiuo atveju ypač reikšmingas yra eksperto gebėjimas plètoti dialogą su kolega, pripažinti besimokančiojo savarankiškumą pagalbos klientui teikimo procese, išlikti išorinio vertintojo pozicijoje.

Refleksija atlieka esminị vaidmeni praktinio mokymosi procese. Ji ịprasmina naują ịgytą patirti. J. Johns (2009) refleksiją apibūdina kaip atsargų, detalų ir realistišką žiūrèjimą ị veidrodị, kuriame matomas pats veikiantis žmogus, ji supantis vaizdas, išgyventi įspūdžiai tam tikros situacijos kontekste. Ilgainiui toks savęs stebejjimas profesionaliam socialiniam darbuotojui tampa gyvenimo ịgūdžiu, leidžiančiu išlikti atviram ir jautriam atsirandančioms galimybėms ir alternatyvoms. Gebejjimas reflektuoti ypač svarbus tada, kai praktikas susiduria su nauja keblia situacija, kurią jis bando išspręsti, ịveikti. Reflektuojant ị problemą ar situaciją bandoma pažvelgti iš naujo, kitaip, galimi nauji sprendimai, naujos ịžvalgos. Be to, labai svarbu, kad socialinio darbo profesionalas gebètų reflektuoti ne tik atliekamą veiklą, bet ir apimtų visą profesinį ,žinojimą“, ịtraukiant ir buvusią patirtį. Taip retrospektyviai apibendrinama patirtis gali išlikti reikšminga ir ateityje. Refleksijos supratimas praplečiamas patirtinio mokymosi procese, kai reflektuojant ne tik bandoma susivokti veikloje, bet siekiama keisti savo profesinio elgesio modeli (Jarvis, Gibbson, 1997). 
Siekiant atrasti individualius profesionalumo plètotės būdus, ieškant atsakymo ị klausimą, kaip mokytis praktinèse situacijose, reikšmingas yra profesionalus supervizoriaus palydejjimas. Supervizijos svarba išryškejja, kai svarstoma profesionaliai intervencijai būtinų teorinių ir praktinių žinių integravimo būtinybė, kuriant naujoms situacijoms aktualias žinias. Esant netikètai ir visada netipinei kliento situacijai patirtinio mokymosi procese įgytos praktinès žinios reflektuojamos, konceptualizuojamos ir modifikuojamos. Tai vienas didžiausių iššūkių praktikos procese, reikalaujantis žinoti apie tai, kuris kuria ir numato alternatyvas žinoti kaip (Jarvis, 2001). Viena pagrindinių supervizoriaus užduočių - padėti susieti praktines žinias, igytas veikiant praktikos vietoje (žinojimas kaip), teorinių studijų metu igytas žinias, apimančias ịvairias mokslo disciplinas (žinojimas kodèl), ir integruojant šias abi epistemas susikurti profesines žinias (žinojima apie tai). Sistemindamas, susiedamas tris skirtingas epistemas, atpažindamas jose besikartojančius elementus, pasitelkęs intrapersonalinę ir tarpasmeninę komunikaciją, socialinis darbuotojas plètoja savo profesionalumą.

Apibendrinant galima teigti, kad užtikrinant dialogu grindžiamą komunikaciją, organizacijoje gali būti sukurtos tinkamos darbo ir mokymosi sąlygos, igalinančios darbuotojus plètoti profesinę kompetenciją. Tačiau jei organizacijoje stebima menka bendradarbiavimą užtikrinančios komunikacijos raiška, jei dirbama mechaniškai, nereflektuojant, socialinių darbuotojų veikla gali tapti statiška ar net prastejjanti, kelianti vidinius konfliktus, slopinanti motyvaciją mokytis, atnaujinti ir tobulinti savo veiklą.

\section{Santykis tarp socialinio darbuotojo ir kliento: vaikų dienos centrų patirtis}

Trečioje straipsnio dalyje analizuojamos empirinès profesinio identiteto formavimosi prielaidos, aktualizuojant komunikacinès kompetencijos plètotę pagalbos šeimai procese. Šioje dalyje pristatomi disertacinio kokybinio tyrimo rezultatai (Eidukevičiūte, 2013). Tyrimas atliktas, vadovaujantis hermeneutine perspektyva. Tyrime dalyvavo 5 socialiniai darbuotojai, dirbantys nevyriausybinėse organizacijose, kurios teikia vaikų dienos centrų paslaugas.

Vaikų dienos centrai siekia suteikti šeimai tokias paslaugas, kurios igalintų šeimą užtikrinti vaiko gerovę, išvengti šeimos, kaip vieneto, išardymo ir vaikų perkèlimo ị globos sistemą. Pagrindinis socialinių darbuotojų veiklos tikslas - igalinti šeimą kaitai. Todèl santykis su suaugusiu šeimos nariu tampa esminiu pagalbos teikèjo profesionalo uždaviniu. Gebẻjimas užmegzti keičiantị santykị intervencijos procese - iššūkis socialinio darbuotojo profesionalumui. D. Harkness, A. Kadushin (1983), apibūdindami santykio su klientu kūrimo procesą, pasitelkia tilto me- 
taforą. Taip pabrèžiama komunikacijos kanalų, kuriais informacija, žinia lengvai keliauja, pasiekdama abiejuose krantuose esančius asmenis, svarba. Kad žinios sėkmingai „keliautu“", reikšmingos intervencijos metu vyrauja emocijos. Nuo santykio kokybės priklauso, ar bus užtikrintas aktyvus kliento įsitraukimas (dialogas) pokalbio metu ir pokyčio igyvendinimas santykiui pasibaigus. Saugumas, pasitikejimas, patikimumas - esminiai reikalavimai intervencijos procese, kai klientas bando ịveikti nerimą, ịtampą ir pavojų. Pastarieji jausmai būdingi vaikų dienos centro klientu tapusios šeimos gyvenime.

Toliau tekste aptariamos temos, išryškejjusios analizuojant interviu tekstus, pateikiami interviu fragmentai, reikšmingi atskleidžiant dviejų tyrimo dalyvių sampratas. Abu tyrimo dalyviai - socialiniai darbuotojai, turintys pakankamą praktinės veiklos patirț, dažniausiai išlieka pirminèje pagalbos proceso fazėje - kontakto užmezgimo situacijoje. Pirmuoju atveju tikimasi šeimos iniciatyvumo, bet ji lieka „nematoma“. Komunikuojama dažniausiai tik su motina, o jos objektas - vaiko elgsena. Leonas kalba apie mamą, kuri domisi vaiku, ateina ị vaikų dienos centrą pasiteirauti, kaip jam sekasi. Tyrimo dalyvis, pristatydamas šeimos situaciją, neịvardija nè vienos savo profesinès veiklos. Mamos domèjimasis vaiko interesais atskleidžia pasiektą pasitikejjimą ir profesinị pripažinimą. Vaiko interesai yra socialinio darbuotojo ir mamos komunikacijos objektas. Iૃžengti ị privatų šeimos gyvenimą negalima, taigi socialinio darbuotojo pagalba suaugusiojo gyvenime yra neịmanoma.

Leonas ištraukoje [3.2.194] pristato socialinio darbuotojo ir kliento santykio galimybes pradinėse intervencijos fazèse. Pirmasis kontaktas su tèvais atsiranda, kai vaikas pradeda lankyti dienos centrą. Tyrimo dalyvis pabrèžia, kad jam svarbu palaikyti bendradarbiaujančius santykius su klientais. Tačiau, jo teigimu, tèvai turètu patys motyvuotis pokalbiui su socialiniu darbuotoju. Profesinis santykis, kurị socialinis darbuotojas kuria su klientu, suprantamas kaip savaiminis. Pagrindinis Leono, kaip socialinio darbuotojo, tikslas - surinkti informaciją apie šeimą. Kalbėdamas apie socialines paslaugas tėvams vaikų dienos centre tyrimo dalyvis pirmiausia pabrèžia laiko, kuris būtinas santykiui su klientu užmegzti, trūkumą. Leonas ịsitikinęs, kad puoselèjant socialinio darbuotojo ir tẻvų tarpusavio santykị pirmiausia būtina, kad tèvai patys domètųsi dienos centru ir jame dirbančiais darbuotojais, pasitelkdami ir kitų vaikų tėvus. Tyrimo dalyvio supratimu, toks atsitraukimas sudaro pagrindą abipusiam pasitikejimui. Nors belaukiant santykio užmezgimo, šeima nustoja lankytis vaikų dienos centre.

Vaikų dienos centro teikiamos paslaugos ir sąlygos, kodèl šeima tapo vaikų dienos centro klientu, Leonui neaiškios. Jo kalba apie kuriamą santykị tarp paslaugu gavejjo ir teikejjo konkrečiais pavyzdžiais neiliustruojama, dažniau pateikiamos 
prielaidos. Tyrimo dalyvis teigia, kad socialinio darbuotojo ir kliento santykis tyrètų vystytis natūraliai, priverstinai nesikišant ir tikintis iš kliento veiksmų, kurie inicijuotu jo, kaip socialinio darbuotojo, veiksmus. Leono teigimu, abipusis pasitikèjimas priklauso nuo gerų aplinkinių atsiliepimų apie dienos centrą. Socialinio darbuotojo ir tėvų ryšys tyrimo dalyviui yra savaiminè vertybė, kuri dar ir labai trapi. Tikimasi, kad tèvai patys motyvuosis pokyčiui ir patys ieškos socialinio darbuotojo. Poreikio keistis pripažinimas traktuojamas kaip pagalbos procesas. Socialinio darbuotojo ir kliento komunikacija ị ši procesą neitraukiama, kaip pageidautina profesinè veikla. Remiantis patirtinio mokymosi raidos modeliu, galima teigti, kad tyrimo dalyvio sampratos atskleidžia pirmaji - naujoko profesionalizacijos etapą.

\subsubsection{7. bet bet ar ne per mažai paslaugu tèvams?}

3.2.188. ${ }^{0}$ labai geras klausimas. ${ }^{0}(.3)$ aš sakau vèlgi tam kad galètum su tèvais vystyti tolesnį darbą visų prima reikia pagauti tą gera ryši . (.) o tam reikia laiko. (.2) $\downarrow^{0}$ tam reikia laiko. ${ }^{0}$ ir kartais to laiko neužtenka todèl kad, klientai keičiasi. (.) nu ta šeima tiesiog ne tai kad pabėga, bet jau pakeičia gyvenamą vietą ar ne, ir jos jau nebèra. viskas. 3.2.188.

3.2.189. ir tas tas užtrunka? (.) ir nepasitiki jumis?

3.2.190. iš pradžių taip. aš negaliu sakyt kad nepasitiki negaliu sakyt, kad pasitiki. ateina jie pirmiausiai taip, (.) na, (.) atsargiai truputèl̨ išsiklausinejja. kas čia? kaip? (.2) jeigu būna iš anksčiau čia gyvenę ar ne, tarkim centro rajone. yra pažįstami žmonès, ten tarkim kaimynai. gal ten kažką tu girdejjai apie tą dienos centrą, ar kažkas tai tokio. taip po truputèli. kodèl tas dienos centras nori kad mūsų vaikai ateitų? kodèl jis nori kad mes lankytumėmès jame? nu toks lyg ir apžvalgomasis toks ir po truputeli vyksta. a:a labai yra faina tarkim pabendrauti su tèvais per kažkokias tai šventes. nes tada susirenka daugiau tévu, ir jie pabūna tokioj grupelèj, jie tarkim ir neformaliai pasišneka, tarkim be socialinio darbuotojo, ar tai atvykstant ar tai išvykstant. (.) va ir, nu po truputèli užsimezga toki santykiai. (.) kartais ir téveliai vyksta su mumis tarkim ị keliones. (.) nu kur nors netoli mes ten kažkur tai ar mieste, Kaune, vyksta. ar ne kaip aš minèjau ten gatvès piešimo akcijos. va:a ateina dar tèvai ten. 3.2.190.

3.2.191. bet tai vyksta viskas po truputi, žingsnelis po žingsnelio?

3.2.192. taip. iš tikrujų tai jo, po truputèli žinokit. nes (.2) ta tokia staigi intervencija visų pirma tu taip staigiai ir ne nepamatysi visų problemų kurios, kurios yra toj šeimoj. tu gali matyt tas išorines. o vidinių, dél ko ten tarkim (.) geria ar ne, dèl ko su tais vaikais blogi santykiai, arba ko tụ pinigu nèra. hh tu matai kad taip yra, bet kodèl taip yra taip greit neišsiaiškinsi. (.) dèl to po truputèli viskas, taip žingsnis po žingsnio, ir galų gale jeigu staigią intervenciją kažkokią taikysi numatęs tik tai tą išorinę problemą. tai kaip jūs ir minèjot gali prarast tą šeimą dẻl staigios intervencijos. 3.2.192. 
Tyrimo dalyvé Justina, dirbanti socialine darbuotoja vaikų dienos centre, pasakojo apie organizacijoje veikiančią tèvų savitarpio pagalbos grupę. Išvengti profesinio ekspertavimo tèvų grupejje jai leido tai, kad ji neturi vaikų. Tai, jos nuomone, sukūrè palankias sąlygas, kurios paskatino tèvus dalintis patirtimi, o jai nereikèjo būti eksperte. Justina sudarẻ sąlygas tẻvams aptarti savo problemas ir ieškoti sprendimo būdų. Sunkumų, kurių kyla šeimoje, pagrindas, jos teigimu, ne tèvų motyvacijos trūkumas ar netinkama moralè, bet finansinių šaltinių, žinių, igūdžių, kurie padètų ịveikti situaciją, trūkumas. Justinai pavyksta susieti subjektyvias ir objektyvias šeimos sunkumų priežastis ir puoselèti pagalbos santykị.

\subsubsection{3. suprantu. (.) ir tada kaip tu, (.) aš galvoju nu (.) kada tau yra pavyzdžiui sékmingas atvejis? (.) kada tu jautiesi kad nu<...>}

2.1.214. iš tikrujų aš geriausiai tai aš skaitau kad tada kai bendradarbiauja tèvai. kai jie patys kažką tai stengiasi daryt ir jiem nu ta prasme ne tik tu vaiku rūpinies, bet ir jie kažką daro dèl vaiko ir dèl savęs. tai man tai yra nu didžiausias pasiekimas, kai jie eina ị kontaktą ir patys bendradarbiaut bando.] 2.1.214.

2.1.215. [po kiek laiko tas ivyksta?

2.1.216. ne tai kad aš turiu jų ieškot. (.3) nu nežinau gal po kokių::ų su kuriuo gal kažkaip skirtingai, nes yra vieni kad jau po kelių mėnesių:u aiškiai matosi kad yra linkę ị kontaktą. nu po kokių pusès metų tai jau matosi. (.) tie patys dabar kurie eina ị kontaktą. ${ }^{\circ}$ bet tai žinai yra tokių kurie visai neina ${ }^{0}$. ir pas mus dar yra ta grupelè kas dvi savaites tai kas pasilieka grupelèj irgi pasijaučia kad labai gerai jiem. 2.1.216.

\subsubsection{7. koks tas tos tavo grupelès tikslas?}

2.1.218. nu kaip ir savitarpio pagalbos žinai ten informacija maždaug pasidalint, bet iš esmès tai:i jie tarpusavyje pasidalina savo problemom ten savo ką jie žino, ką jie pasiekẻ kaip ten kokioj ịstaigoj kokie kokios plonybės kad ten kažką padaryti. bet iš esmès kaip aš sakau kad jie:e išsikalba vieni su kitais, nes vis tiek kai kalbasi daugiavaikè mama su daugiavaike tai jai jau nei ji kalbasi su manim kai aš neturiu vaikų žinai. nu vis tiek jai kažkaip kitaip turèjo. man tai kažkaip savitarpio pagalba ten labai, toks kvepia dalykas. (.) ir labai labai gerai pasijaute kad tie kurie eina ị grupelę pradèjo, labai su manim irgi su manim labai geri santykiai pasidarè. ${ }^{0}$ bet aišku yra tie kurie neina. ${ }^{0}$ 2.1.218.

2.1.219. kiek ju yra, kurie $n u<\ldots>$

2.1.220. tai eina tie kurie stengiasi kažką daryt. šeši penki žinai.

Tyrimo dalyvė išryškina tėvų savitarpio pagalbos grupès tikslą - įveikti vaikų apleistumą ir pagerinti savo, kaip tèvų, situaciją. Justinos teigimu, tèvai, suinteresuoti keisti savo situaciją, atranda galimybių puoselèti bendradarbiaujančius tarpusavio santykius. Tyrimo dalyvė pabrèžè santykio svarbą. Kaip daugelis šiame tyrime dalyvavusių socialinių darbuotojų ji tai vadino kontaktu. Nors B. R. Campton 
ir B. Galaway (1999) kontaktą apibūdina kaip pradinį pagalbos proceso etapą, tyrimo dalyvè pabrèžè ir laiko svarbą socialinio darbuotojo bei kliento santykio raidai.

Remiantis patirtinio mokymosi raidos modeliu, galima teigti, kad antruoju atveju tyrimo dalyvės sampratos atskleidžia įgalinančio socialinio darbo su šeima, grindžiamo dialogo kultūra, prielaidas. Šiuo atveju, šeima „matoma“ kaip aktyvus ir savarankiškas dialogo partneris pagalbos procese. Tačiau galima pastebėti pačios darbuotojos nepakankamą pasitikèjimą savo kompetencija. Tai leidžia teigti, kad tyrimo dalyvè reflektuoja savo patirti. Jai aktualus praktiko eksperto arba supervizoriaus palydejjimas, kuris leistų pereiti ị antrajj - kompetentingumo etapą profesionalizacijos procese.

\section{Išvados}

1. Igalinimo nuostatos, grindžiamos tolerancija ir dialogu, akcentavimas pagalbos žmogui procese skatina numatyti tokias socialinès pagalbos strategijas, kurios leistų plètoti ne tik tiesioginès veiklos, bet ir bendradarbiavimo su klientu, kolegomis, vadovu patirties reflektavimą. Patirtinis mokymasis, grindžiamas refleksija ir praktiko eksperto ar supervizoriaus palydèjimu, užtikrintų nuolatinị socialinių profesijų atstovų veiklos tobulinimą, eksperimentuojant, pritaikant naujas žinias apie vaiko ir jo šeimos, kaip kliento, situaciją, aktyviai dalyvaujant socialinio darbo profesinio identiteto formavimosi procese.

2. Empirinis tyrimas atskleidè du esminius profesionalizacijos nuostatų realizavimo trukdžius, nulemtus socialinių darbuotojų ir šeimos, kaip kliento, komunikacijos problemų:

a) socialiniai darbuotojai pagalbą teikianti santyki galëjo kurti tik su mama, išskirtiniais atvejais - su vaikų tèvu. Atliekant tyrimą išryškèjo pagalbos procese vyraujantis požiūris, kad moteris iš prigimties geba suteikti vaikams adekvačią ir pakankamą globą. Taigi socialiniam darbuotojui kuriant santykị su mama galimi pokyčiai šeimoje. Kiti šeimos nariai šiame procese tarsi nedalyvauja;

b) socialiniai darbuotojai, pasakodami klientų ir pagalbos jiems istorijas, intervenciją dažniausiai apibūdindavo kaip konkrečiu faktų apie šeimą rinkimą. Rečiau tyrimo dalyviai kalbèdavo apie kuriamo santykio su klientu raidą, pokyčius šeimoje.

3. Apibendrinus straipsnyje pateikiamos analizès rezultatus, išryškejja praktinių socialinio darbo žinių kūrimo problemiškumas, kai nepakankamai apmąstoma asmeninė veikla, nepakankamai reflektuojamas ir analizuoja- 
mas individualaus patirtinio mokymosi procesas bei jo rezultatai; išryškèja praktiko eksperto arba supervizoriaus palydejjimo būtinybė patirtinio mokymosi procese, įsivertinant, susiejant praktines žinias, ịgytas veikiant praktikos vietoje, teorines žinias ir sukauptas profesines žinias. Toks palydejjimas ịgalina praktiką sisteminti situacijose besikartojančius elementus, refleksijos dèka plètoti savo, kaip socialinio darbuotojo, profesionalumą.

Gauta 20141012

Pasirašyta spaudai 20141222

\section{Literatūra}

Bell, D. (2003). Kapitalizmo kultūriniai prieštaravimai. Vilnius: Alma littera.

Bourdieu, P. (1994). Language and Symbolic Power. Cambridge: Oxford.

Brunevičiūtè, R., Večkienė, N. P. ir kt. (2011). Practical preconditions for the development of the interdisciplinary collaboration competence in healthcare. Santalka: filologija, edukologija 19 (2): 132-140. Vilnius: Technika.

Burnard, P. (2002). Learning human skills - an experiential and reflective geode for nurses and health care professionals. Elsevier Science. Ltd.

Campton, B. R., Galaway, B. (1999). Social Work Process. Brooks/Cole Publishing Company.

Dirgelienè, I. (2008). Teorijos ir praktikos ryšio plètotė socialinio darbuotojo profesinèje veikloje. Acta Pedagogica Vinensia 20: 90-101.

Dreyfus, H. L. (1997). Intuitive, Deliberative, and Calculative Models of Expert Performance. In: C. E. Zsambok, G. A. Klein (eds.). In Naturalistic Decision Making. Lawrence Erlbaum Associates.

Dreyfus, S. E., Dreyfus, H. L. (1980). A Five Stage Model of Mental Activities Involved in Direct Skill Acquisition. University of California: Berkley.

Grossman, S. C. (2007). Mentoring in nursing - a dynamic and collaborative process. Springer Publishing Company Ltd.

Grebliauskienė, B., Večkienė, N. (2004). Komunikaciné kompetencija. Komunikabilumo ugdymas. Vilnius: Žara.

Eidukevičiūtė, J., Kiznytė, N. (2009). Studentų adaptacijos kompleksiškumas organizacijoje praktikos proceso kontekste. Socialinis darbas. Patirtis ir metodai 3(1): 91-104. Kaunas: VDU.

Eidukevičiūtė, J., Večkienė, N. P. (2009). Tutoriaus ir mentoriaus funkcijos socialinio darbo studentų mokomosios praktikos procese. Profesinis rengimas. Tyrimai ir realijos 17: 204-231.

Eidukevičiūtè, J. (2011). Mokomosios socialinio darbo praktikos turinio sistemiškumo prielaidos. Socialinis darbas. Patirtis ir metodai 8(2): 149-162. Kaunas: VDU.

Eidukevičiūtè, J. (2013). Family Social Work Practices in the Context of Transitional Lithuanian Society. Acta Universitatis Lapponiensis 250. Lapin yliopistokustannus: Rovaniemi.

Jarvis, P. (2001). Mokymosi paradoksai. Kaunas: VDU.

Jarvis, P., Gibosn, S. (1997). The Teacher Practioner and Mentor in Nursing, Midwifery. Health Visiting, and Social Services. Nelson Thornes.

Johns, J. (2009). Becoming a Reflective Practitioner. Wiley-Blackwell Publishing.

Kadushin, A., Harkness, D. (2002). Supervision in social work (4 $4^{\text {th }}$ ed.). Columbia University Press.

Kavaliauskienė, V. (2005). Socialinio darbo, kaip pagalbos žmogui profesijos, raidos aspektai. Acta Pedagogica Vinensia 15: 230-239.

Lorenz, W. (1998). Social Professions for a Social Europe. - European Dimensions in Training and practice of Social Professions. Ostrava: University of Ostrava.

Payne, M. (1996). What is profesional social work? Vebture Press.

Večkienė, N. P., Povilaikaite, S. (2005). Socialinio darbo sampratos kaita. Profesinis rengimas: tyrimai ir realijos 9: 130-138.

Večkienė, N., Dirgèlienė, I. (2010). Paramą teikiantis bendradarbiavimas socialinio darbo procese: nuo idejjos link praktikos? Socialinis ugdymas 11 (22): 35-43. 
Večkienė, N. P. (2011). Bendradarbiavimu grindžiama socialinė partnerystė: studentų praktikos organizavimo teorinès prielaidos. Socialinis darbas. Patirtis ir metodai 8(2): 113-134. Kaunas: VDU.

Žorga, S. (2006). Competences of a supervisor. Ljetopis socijalnog rada 14 (2): 433-441.

\title{
COMMUNICATION COMPETENCE IN SEARCHING FOR PROFESSIONAL IDENTITY
}

\section{Julija Eidukevičiūtė, Nijolė Petronèlė Večkienė}

\author{
Summary
}

One of the essential characteristics of knowledge society and its main challenge is the multidisciplinary nature of such society as this actualizes the learning to communicate in action with different individuals and members of different subcultures (Brunevičiūtè et al., 2011). In such society the new requirements are raised for the person and they impact the change of interaction between the person and environemnt, the changing demands, and lasting new type problems. On the other hand the preservation and development of human resources and opportunities of individual person independent living becomes the main characteristic of knowledge society. In this cultural-social environment as a must the condition of ability to understand arises. But objective reality of knowledge society - convergence of sciences may cause difficulties in communication between representatives of different science fields. By denying such reality, the individuals depending to different social activity fields with different professions working in one organization, in one project team can hardly communicate (Večkienè, 2011). In search for the communication potential there is necessity to create conditions for collaboration experience development. The research of the current decade in the mentioned field highlighted essential collaboration problem: is it possible and how it is possible to learn to communicate? (Brunevičiūtė, Večkienė, 2011; Eidukevičiūtè, Večkienė, 2005).

Social work is activity of empirical nature, which is still in search of its own identity, a changing profession. The purpose of the social work is to solve issues, arising due to interaction between individual, community and society. Social worker in order to optimize the client"s life situation and his/her environment which is always complex, is searching for solution possibilities and applies knowledge of various sciences. When providing help for the family, the social worker encounters the complexity of the family as a unit, the individuality of each member of the family and unique experience.

The aim of the paper is to dicuss the helping process for the risk family and the possibility to develop the communication competence in the process of individual 
intervention or group intervention, responding the knowledge society challenges. The problems analyzed in the paper can be described by using Bourdieu (1990) statement the knowledge objects are designed and not written. The social worker while interacting with the client is constructing his/her professional behaviour, language, understanding, thus developing the cognition of his/her activity world. Večkienè (2010) notice that the competence of social workers in practice is expressed in unique way: in particular interaction with the client they uniquely realize the attitude about values, gained knowledge and skills. In order to understand the professional knowledge construction process it is necessary to consider that $h a$ bitus, according to Bourdieu (1990), is historical product which impacts indivual and collective practices corresponding to schemes generated in history. Through the activity habitus ensure the "regularity" of the practice and its stability, the actuality of the past experiences to the present. The particular practice becomes more reliable than all the formal rules or clearly described norms.

In this context the specific paradox shows up. The help for family has been provided during the soviet times. But during these times the parents and children had to keep the directions regulated by state, correspond to norms regulated by state and the ideology was the most important. The individual solution, personal values were not desired and even impossible. The modern attitude to family and its responsibilities are radically different. The family is understood as primary and the most import social system for the child, which takes the main responsibility for his/her social development. Therefore the relationship between the social workers and the family in the process of help should be essentially different. But while creating the enabling help relation with developing professional identity of social worker, social educator (they should be responding to modern context) the insufficiently reflected historical experience, poor cognition of cultural context might become a dangerous obstacle.

The paper follows the learning paradigm and social empowerment methodological guidelines, which emphasize the the position of active and responsible character and the meaning of collaboration which determine the success of professional activity. The paper consists of introduction, 3 parts and conclusions. The first part discuss the context of the social work, which impact interpersonal communication obstacles and arising problems, the necessity to develop communicative competence is emphasized.

The second part discusses the theoretical possibilities of learning to construcet the enabling relationship with family, by emphasizing the experiental learning process and peer communcation of the participants. This part provides models of experiential learning and professionalization, emphasizes the significance of social worker in consultat's role, specifies particularities of each professionalization 
stage which determines the quality of intercommunication and help (Bernar, 2002; Dreyfus, Dreyfus, 1980).

The third part of the paper analyzes the empirical professional identity formation assumpations by actualizing communcative competence development in the helping process for risk family. In this part the results of dissertation's qualitative research are provided (Eidukevičiūtė, 2013). The study was accomplished in accordance to hermaneutic perspective. 5 social workers working in non-governmental organizations which provide services of children day centres participated in the study. The study revealed the problems of communication between social worker and family as a client. Social worker with sufficient practical activity experience usually remains in the primary phase of help process - contact establishment. In one case family proactiveness is expected but it remains "invisible". Mother usually is communicated and the object of communication is child behaviour. Thus, based on the development of experiential learning model, it can be said that the research participant reflects the concept of the first - the newcomer professionalization stage. In the second case, the study reveals the assumptions for the concept of enabling the participants in social work with the family, based on a culture of dialogue. In this case, the family is "visible" as active and self-help in the process of dialogue partner. However, one can notice the lack of confidence in their employee competence. This suggests that the study participant reflects her experience. She needs expert practitioner or supervisor coaching, which would allow going to the second - the expertise professionalization stage of development.

While summarizing the paper provided results of analysis, the pertaining problems of practical social work knowledge development were emphasized when the activity is insufficiently considered, insufficiently reflected. While analyzing the individual process of experiential process the necessity of practitioner-expert or supervisor coaching in the experiential learning process by self-assessing and combining practical knowledge which were gained by acting in practice placement, theoretical knowledge and created professional knowledge. Such coaching enables to systematize elements recurring in situations, develop their professionality of social worker with the help of reflection. 